\title{
PENGAMANAN HAK CIPTA CITRA DIGITAL DENGAN TEKNIK WATERMARKING MENGGUNAKAN METODE HYBRID SVD DENGAN DWT
}

\author{
Ondi Asroni, Dedy Ricardo Serumena
}

Politeknik eLBajo Commodus, Indonesia

Email: ondi817@gmail.com,rserumena@gmail.com

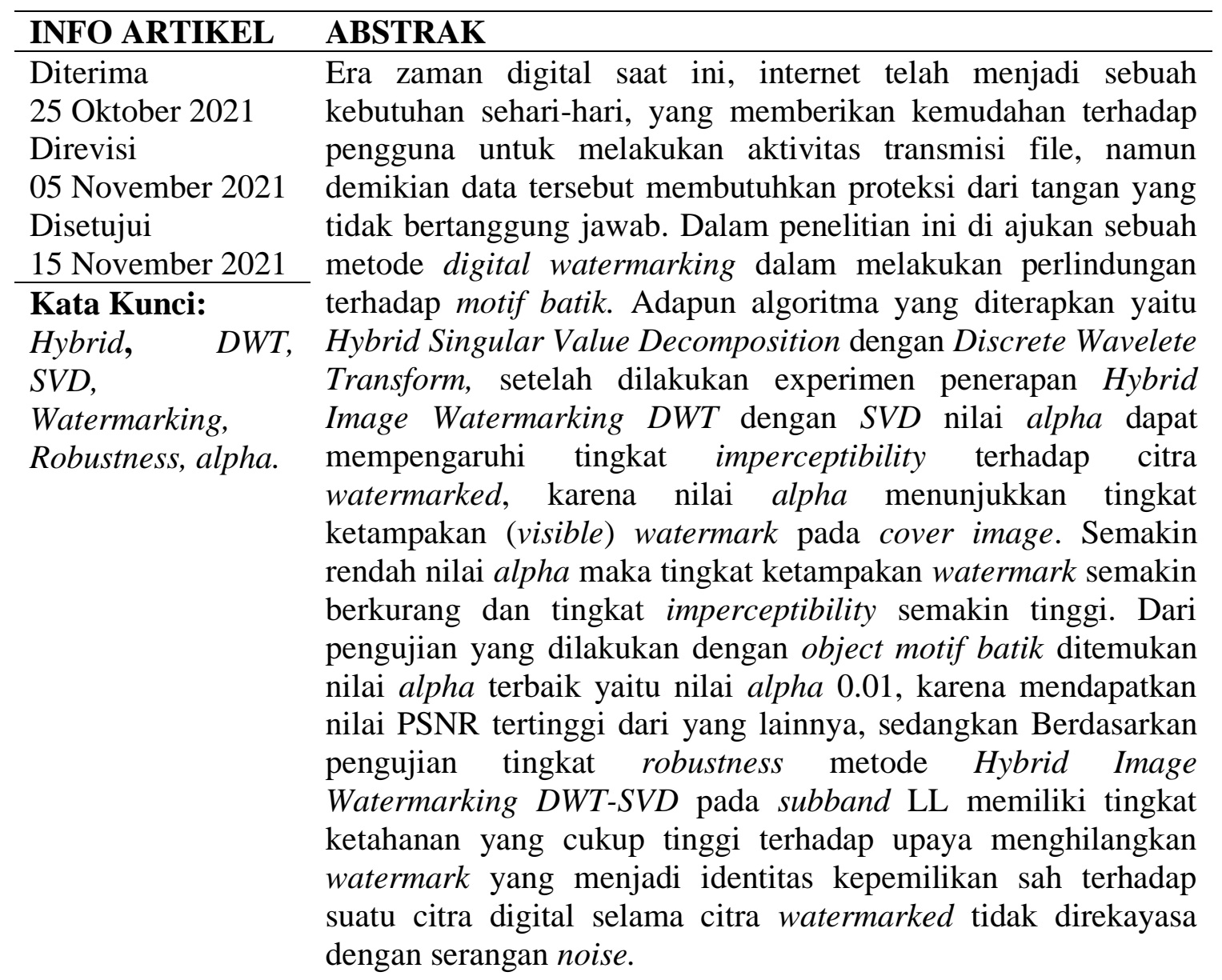

\section{ABSTRACT}

In the current digital era, the internet has become a daily necessity, which makes it easy for users to carry out file transmission activities, however, the data requires protection from irresponsible hands. In this study, a digital watermarking method is proposed to protect batik motifs. The algorithm applied is Hybrid Singular Value Decomposition with Discrete Wavelete Transform, after the experiment of applying Hybrid Image Watermarking DWT with SVD the alpha value can affect the imperceptibility level of the watermarked image, because the alpha value indicates the level of visible watermark on the cover

How to cite:

E-ISSN:

Published by:
Asroni, O., \& Dedy Ricardo Serumena. (2021). Pengamanan Hak Cipta Citra Digital dengan Teknik Watermarking Menggunakan Metode Hybrid SVD dengan DWT. Jurnal Syntax Admiration 2(11). https://doi.org/10.46799/jsa.v2i11.334 2722-5356

Ridwan Institute 
image. The lower the alpha value, the less visible the watermark is and the higher the imperceptibility level. From the tests carried out with the batik motif object, it was found that the best alpha value was an alpha value of 0.01, because it got the highest PSNR value from the others, while based on the Keywords: $\quad$ robustness level test the Hybrid Image Watermarking DWT-SVD Hybrid, DWT, method in the LL subband has a fairly high level of resistance to SVD, efforts to eliminate watermark which is the identity of legal Watermarking, ownership of a digital image as long as the watermarked image Robustness, alpha. $\quad$ is not engineered with noise attacks.

\section{Pendahuluan}

Di zaman era digital saat ini, internet telah menjadi sebuah kebutuhan sehari-hari (Allen, 2002), fasilitas yang ditawarkan cukup beragam, salah satunya adalah featur unggah dan unduh file citra digital, dengan kegitan tersebut semua orang dapat dengan mudah mentransmisikan dan memproleh file dengan bantuan internet saat ini.

Dampak dari kemajuan internet tidak terlepas dari sisi negatif dan positifnya, tercatat dari sosial time bahwa 700 juta pengguna whatsApp, dengan jumlah upload 8,102 perdetik, 1,39 miliyar lebih pengguna facebook setiap hari melakukan upload foto dan terdapat 70 juta poto perhari dengan total perdetiknya sebanyak 810 file poto. Dampak positifnya adalah proses transmisi dan unggah file poto sangat cepat dengan kemajuan teknologi internet saat ini (Gani, 2014), sedangkan dampak negatifnya adalah besar kemungkinan terjadi penyalahgunaan hak atas kekayaan intelelektual (HKI) yang dilakukan oleh pihak-pihak yang tidak bertanggung jawab, dengan demikian perlu adanya sebuah protection perlindungan terhadap file-file poto tersebut.

Metode proteksi terhadap konten multimedia, seperti text, image, grafik, audio, dan video dapat dilakukan dengan menggunakan beberapa metode seperti Digital Right Management (DRM), kryptography, steganography, fingerprint, biometric, digital signatural, enskripsi dan digital watermarking (Ukkas et al., 2017).

Untuk perlindungan hak cipta banyak sekali teknik yang bisa digunakan, salah satu teknik yang sering digunakan adalah Teknik Watermarking (Munir, 2010) atau dapat disebut sebagai tanda air, yaitu teknik atau metode menanamkan atau menyisipkan suatu pesan yang bersifat rahasia ke dalam sebuah pesan lainnya yang jelas tetap terlihat dan dapat menyamarkan pesan tersebut dan keberadaan watermark bisa dibuktikan dengan proses ekstraksi. Dalam metode watermarking teknik penyisipan terbagi menjadi 2 (dua) bagian (Munir, 2010), yaitu pertama teknik domain spasial dan selanjutnya teknik domain frekuensi. Teknik domain spasial penyisipan watermark langsung pada objek, sedangkan domain frekuensi menyisipkan watermark dengan mengubah nilai-nilai komponen frekuensi dengan transformasi.

Sebagai Bangsa Indonesia, tentu ada kebanggan tersendiri akan batik sebagai aset/warisan budaya bangsa (Trixie, 2020), yang telah di kokohkan sebagai warisan budaya bangsa oleh UNESCO (Nurhaida et al., 2015). 
Selanjutnya untuk melindungi Hak akan Kekayaan Intelektual (HKI) (Naoe \& Takefuji, 2008) atas penyalahgunaan terhadap karya intelektual dalam hal ini citra digital "motif batik" perlu adanya Copyright perlindungan dalam hak cipta, digital watermarking digunakan sebagai sebuah cara yang efisien untuk mengatasi masalah HKI pada data multimedia, video, digital dan audio (Chang et al., 2009).

Watermarking merupakan sebuah proses atau teknik penyembunyian Informasi (Huang et al., 2004) yang mengarah pada kepemilikan atau melacak penyalahgunaan hak cipta pada multimedia data seperti video, audio, dan citra digital (Isac \& Santhi, 2011).

Beberapa penelitian telah di lakukan di bidang watermarking yaitu oleh (Chang et al., 2009) penelitian ini menerapkan metode watermarking untuk melindungi gambar medis atas penyalahgunaan yang tidak sah menggunakan algoritma singular value decomposition (SVD) dan particle swarm optimization (PSO) sebagai optimisasi.

Masalah utama yang dihadapi pada semua skema teknik watermarking domain transformasi adalah adanya kriteria penting yang sering konflik, yaitu robustness dan imperceptibility. Dengan menggunakan hybrid skema DWT-SVD, dua kriteria ini dapat diatasi, untuk menghasilkan skema watermarking yang lebih efektif (Azhar et al., 2015).

Beberapa kriteria harus terpenuhi di dalam digital Watermarking yaitu robustness, imperceptibility, dan security (Zhi-Ming et al., 2003). Ketangguhan dari sebuah watermark dapat bertahan dari berbagai serangan disebut Robustness untuk menghilangkannya seperti cropping, scaling, filtering, dan compression. Imperceptibility berkenaan dengan ketidaktampakan watermark yang tidak boleh tampak oleh penglihatan mata manusia, serta tidak menimbulkan degradasi pada citra. Sedangkan Security berarti watermark yang di sisipkan tersebut tidak terdeteksi dengan analisis statistik umum atau metode yang lain.

Beberapa peneletian dibidang watermarking telah dilakukan oleh (Gangadhar et al., 2018) dengan judul "An evolutionary programming approach for securing medical images using watermarking scheme in invariant discrete wavelet transformation" penelitian ini menerapkan metode watermarking untuk melindungi gambar medis atas penyalahgunaan yang tidak sah menggunakan metode singular value decomposition (SVD) dan Particle Swarm Optimization (PSO), Dari penelitian ini menunjukkan Koefisien normalisasi (NC) dan Peak Signal to Noise Ratio (PSNR) dipertimbangkan untuk mengevaluasi kesamaan antara citra medis dan citra medis yang diberi watermark. Algoritma yang diusulkan menunjukkan peningkatan kinerja dalam hal imperceptibility dan ketahanan sedangkan dalam studi kasus yang di usulkan dalam peneletian ini yaitu menerapkan teknik watermarking menggunakan algoritma Singular Value Decomposition di hybrid dengan Descrete Wavelete Transform (DWT) dari berbagai serangan, setelah dilakukan experimen penerapan Hybrid Image Watermarking DWT dengan SVD nilai alpha dapat mempengaruhi tingkat imperceptibility terhadap citra watermarked, karena nilai alpha menunjukkan tingkat ketampakan (visible) watermark pada cover image. Semakin rendah nilai alpha maka tingkat ketampakan watermark semakin berkurang dan tingkat imperceptibility semakin tinggi. Dari 
pengujian yang dilakukan dengan object motif batik ditemukan nilai alpha terbaik yaitu nilai alpha 0.01 , karena mendapatkan nilai PSNR tertinggi dari yang lainnya.

\section{Metode Penelitian}

Jenis penelitian ini adalah jenis penelitian terapan. Yaitu hybrid domain spasial yaitu SVD dan domain frekuensi yaitu $D W T$, keduanya akan di gabungkan untuk menguji tingkat inperceptibility dan robutsness dari berbagai serangan umum, seperti Gaussian noise, Speckle noise, dan lain-lain. Namun pada penelitian ini di batasi dengan tiga serangan yaitu speckle noise, gaussian noise, dan salt and pepper noise. Dengan kebutuhan beberapa hardware dan software di antaranya :

a. Processor Intel (R) Core (TM) i3 CPU M350 @2.27GHz

b. RAM 4,00 GB (3,74 GB usable);

c. System Type 64-bit Operating System, Windows 10 Home

d. SSD $240 \mathrm{~GB}$

e. Matlab R2017b

f. Microsoft word 2016

g. Microsoft excel 2016

Citra digital standar sebagai citra file host dalam peneletian ini di ambil dari http://sipi.usc.edu/database/database.php (Hidayat \& Udayanti, 2011).

Berdasarkan rekomendasi dari peneliti-peneliti sebelumnya yang banyak menggunakan gambar dengan type.jpg yang mendukung kompresi baik secara lossy maupun lossles dan ukuran 512 x 512 piksel yang lazim digunakan oleh peneliti-peneliti dalam bidang Watermarking untuk proteksi pada citra digital. Pada penelitian ini dilakukan tiga (3) tahap pengujian yaitu pengaruh alpha tingkat imperceptibility dan pengujian tingkat robustness.

\section{Teknik Analisis Data}

Adapun teknik analisis data dapat di tunjukkan pada gambar berikut ini;

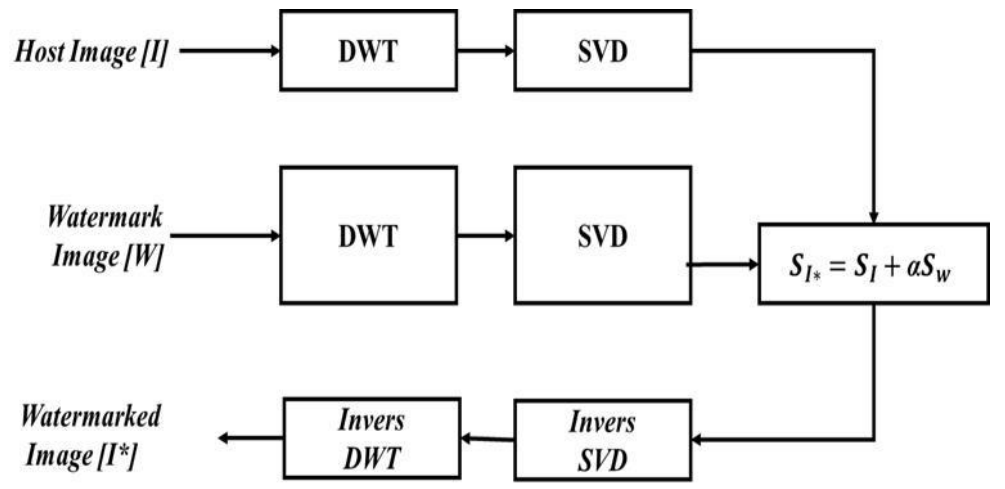

Gambar 1

Diagram Penyisipan Menggunakan Algoritma DWT-SVD 


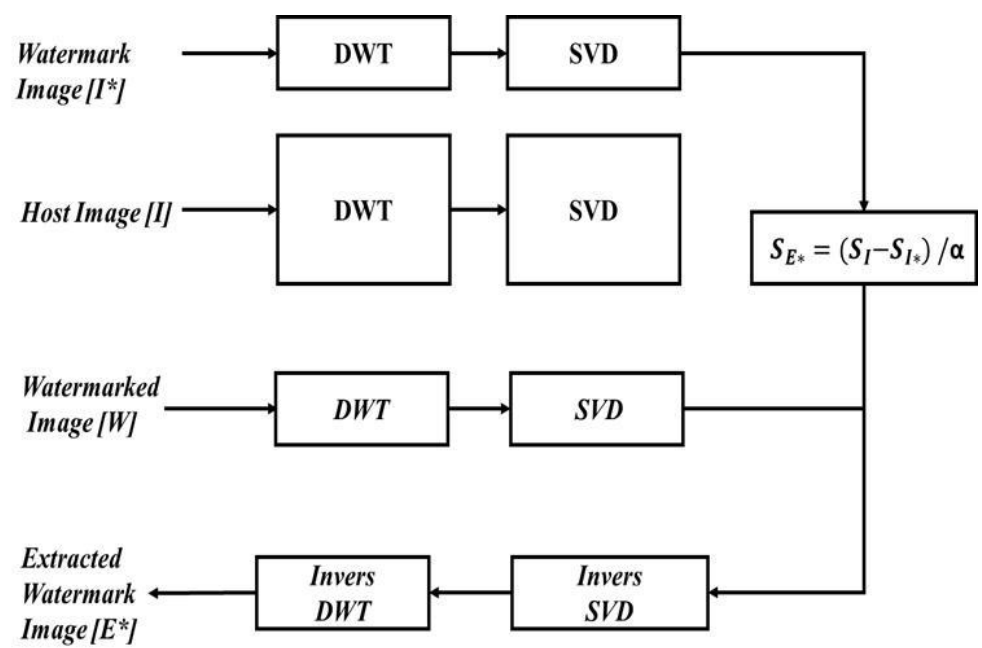

Gambar 2

Diagram ekstraksi menggunakan algoritma DWT-SVD

1. Sebuah file citra (watermark image) dengan format JPEG disisipkan ke dalam sebuah citra induk dengan format JPEG. Penyisipan dilakukan dengan menggabungkan algoritma $D W T$ dan $S V D$ (DWT-SVD). Kemudian diterapkan inverse dari $S V D(I S V D)$ dan inverse dari $D W T$ (IDWT) untuk merekontruksi citra induk hingga mendapatkan watermarked images.

2. Dari watermarked images akan diperoleh nilai PSNR yang menentukan kualitas citra tersebut. Semakin tinggi nilai $P S N R$ maka semakin baik kualitas dari citra tersebut.

3. Proses ekstraksi juga dilakukan dengan menggabungkan algoritma $D W T$ dan $S V D$ (DWT-SVD) sehingga diperoleh extracted watermark images.

4. Dari extracted watermarked images akan diperoleh nilai $C C$ yang menentukan kemiripan antara extracted watermark images dengan watermark image. Rentang nilai dari $C C$ adalah antara -1 dan 1. Jika nilai $C C$ mendekati nilai 1 maka dikatakan bahwa extracted watermark images memiliki kemiripan yang besar dengan watermark image. 


\section{Model Yang Di Usulkan}

Berikut Adalah Model /Metode Yang Diusulkan Dalam Penelitian Tugas Akhir Ini

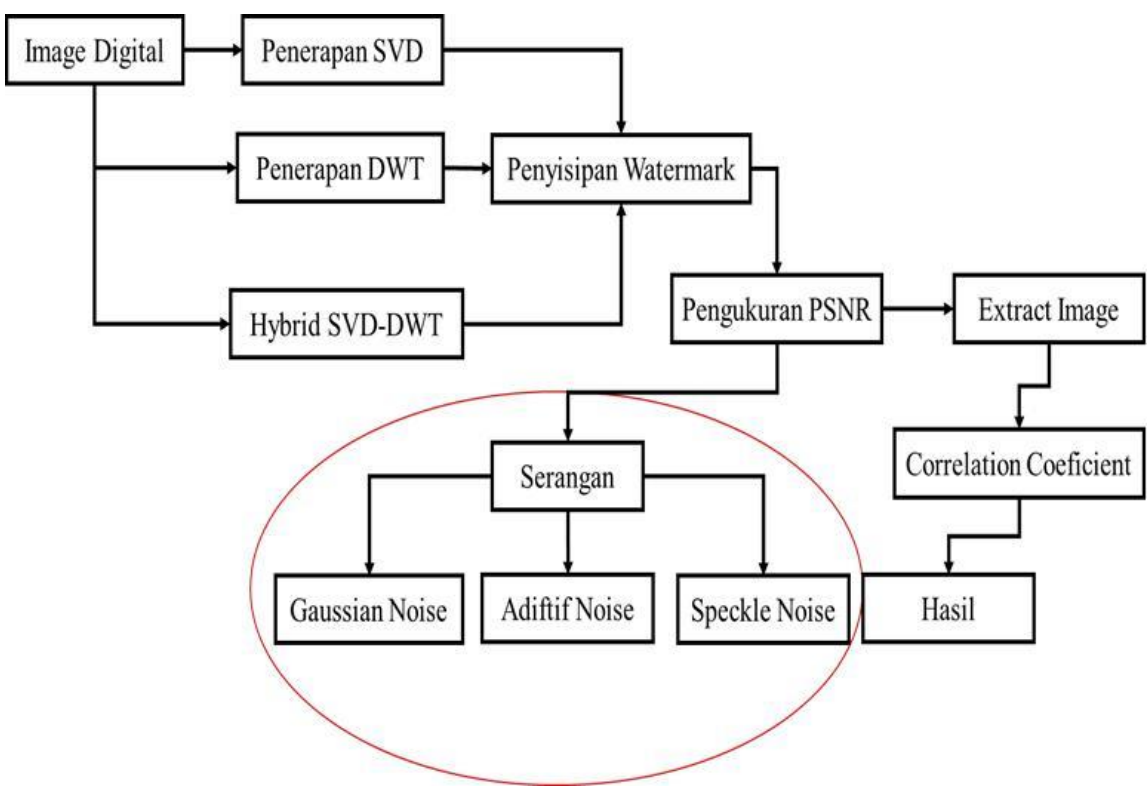

Gambar 3

Usulan serangan untuk image Watermark

Berdasarkan diagram diatas, usulan penelitian dapat dijelaskan dengan langkahlangkah sebagai berikut.

1. Citra digital sebagai host image adalah citra digital batik yang berupa Citra batik RGB color sebagai objeck experiment.

2. Kemudian metode yang diterapkan yaitu singular value decomposition, descrete wavelete transform, dan Hybrid kedua metode tersebut. Untuk membuktikan tingkat inperceptibility masing-masing metode.

3. Image watermark menggunakan logo kota surakarta yang akan di sisipi pada image cover sementara pada cover image standar watermark menggunakan logo kampus dengan size masing-masing image 512 x 512 pixel.

4. Untuk menguji robutsness masing-masing gambar setelah di watermark maka diuji dengan PSNR (Peak signal to noise ratio) dengan menghitung nilai MSE (mean sequare Error) terlebih dahulu, kemudian dilakukan perhitungan PSNR dengan rumus.

5. Untuk mengukur nilai tingkat inperceptibility setelah dilakukan penyisipan gambar kemudian image di ekstrak untuk memproleh nilai Correlation Coeficient.

Serangan dilakukan setelah image watermark di sisipkan pada host image, yang terdiri dari tiga noise yaitu gaussian noise, speckle noise, adiftif noise dan akan menghasilkan nilai Coeficient Corrolation. 


\section{Langkah Penyisipan Image Watermarking}

Langkah penyisipan dengan $D W T$ dapat dilihat pada bagan di bawah berikut:

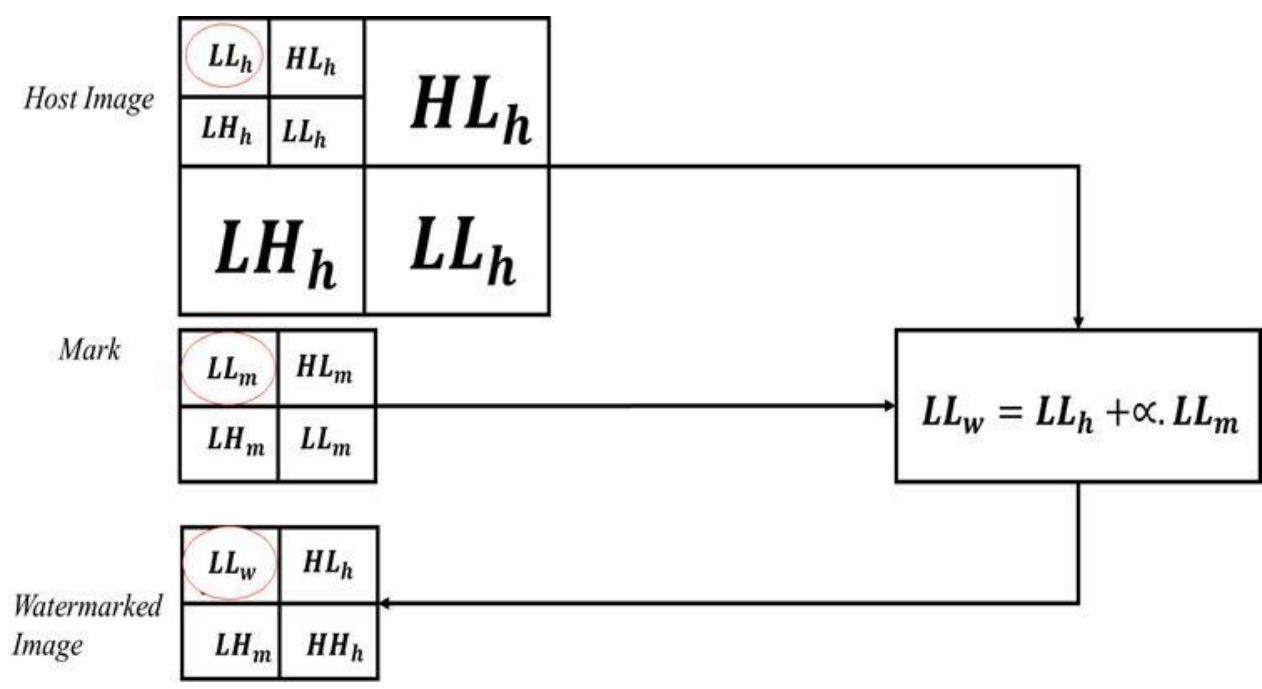

Berdasarkan diagram diatas, prosedur penyisipan menggunakan algoritma $D W T$ dapat dijelaskan dengan langkah-langkah sebagai berikut.

a. Input cover image sebagai host image.

b. Terapkan algoritma $D W T$ pada host image, citra akan terbagi menjadi 4 subbands yaitu LL, HL, LH dan HH.

c. Pilih subband yang akan disisipi watermark image, contoh subbands LL level-2.

d. Input image watermark.

e. Terapkan algoritma $D W T$ pada watermark image, maka citra akan terbagi menjadi empat subbands diantaranya LL, HL, LH, HH.

f. Pilih LL pada watermark image.

g. Kemudian terapkan algoritma $S V D$ pada subband yang telah dipilih pada host image (subband LL level-2). Proses ini akan menghasilkan matriks orthogonal U (ULL level-2), matriks diagonal S (SLL level-2) dan transpose dari matriks orthogonal V ([VLL level-2] $]^{\mathrm{T}}$ ).

h. Terapkan algoritma DWT pada watermark image, citra akan terbagi menjadi 4 subbands yaitu LLw, HLw, LHw dan HHw.

i. Pilih subband yang akan disisipkan pada host image, contoh subband wLL level-2.

Kemudian terapkan invers $D W T$ dengan memodifikasi subband LL dengan nilai untuk mendapatkan watermarked image.

\section{Correlation Coeficient (CC)}

Tingkat kemiripan antara citra watermarked hasil ekstraksi (extracted Watermark image) secara kuatitatis diukur menggunakan Correlation Coeffitient (CC) didefinisikan sebagai berikut. 


\section{Hasil dan Pembahasan}

\section{Design Dari Aplikasi Hybrid SVD dan DWD}

Pada penelitian tentang penggabungan algoritma Watermarking yaitu $D W T$ dengan $S V D$ untuk proteksi terhadap citra digital batik dilakukan beberapa tahapan untuk meneliti tingkat keberhasilan dan keamanan dari algoritma yang diterapkan khusus pada citra digital RGB. Tahapan penelitian dimulai dari pembuatan aplikasi Watermarking kemudian melakukan percobaan embedded gambar dan pemberian serangan untuk mengetahui tingkat ketahanan algoritma, selanjutnya melakukan analisa terhadap hasil embedded dan ekstraksi watermark setelah diberikan serangan.

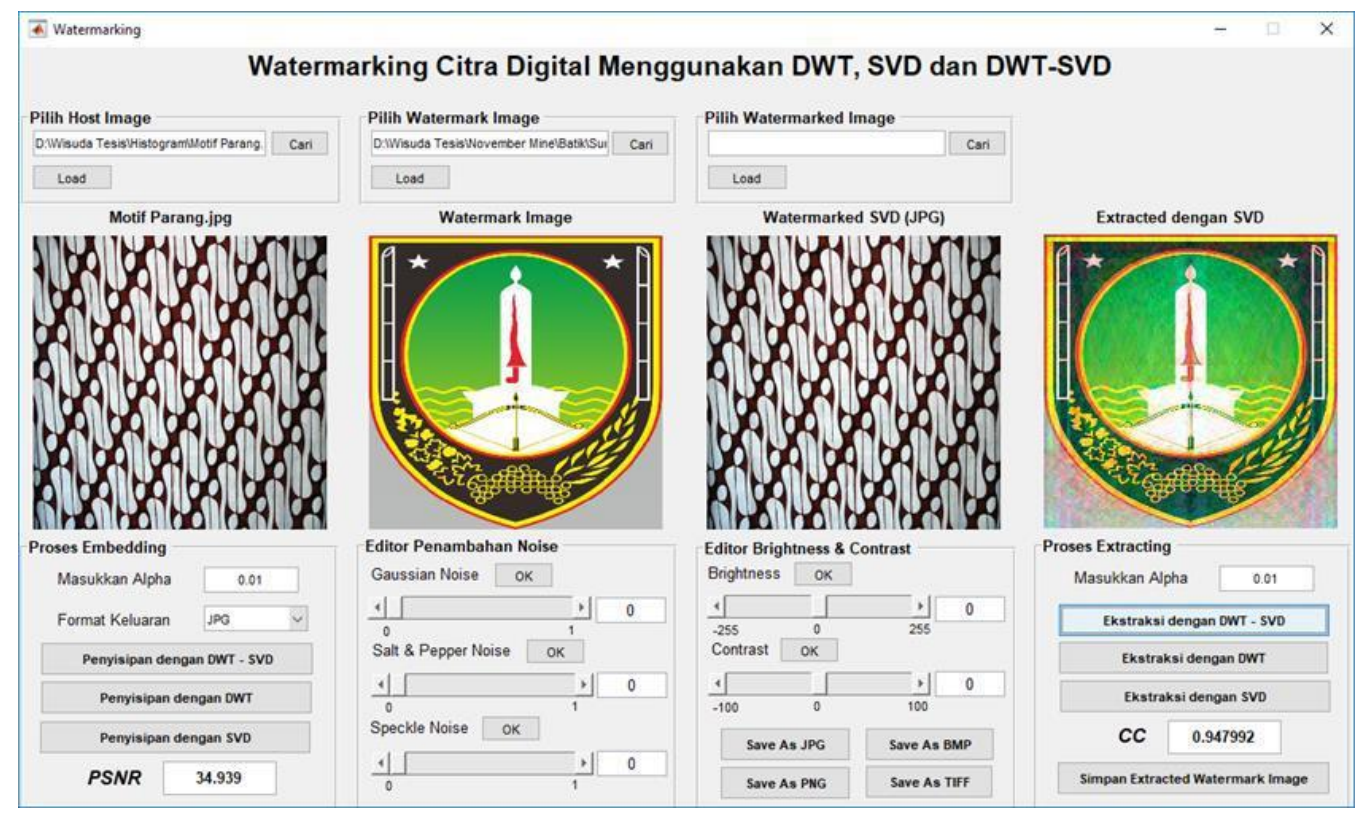

Gambar 4

GUI Program Watermark Untuk Protection Citra Digital Pada Motif Batik

\section{Peak Signal to Noise Ratio (PSNR)}

Peak Signal to Noise Ratio (PSNR) merupakan perbandingan nilai maksimum dari sebuah sinyal yang di ukur dengan besarnya derau yang berpengaruh pada sinyal tersebut. PSNR biasanya diukur dalam satuan decibel $(d B)$. PSNR lebih sering di gunakan untuk mengetahui perbandingan antara kualitas host image sebelum dan setelah di sisipi pesan. Namun untuk mengetahui PSNR kita harus menghitung mean sequare Error (MSE). MSE sendiri merupakan nilai error kuadrat rata-rata antara image asli dan watermark images (Rafigh \& Moghaddam, 2010).

PSNR merupakan parameter untuk mengukur kualitas atau tingkat imperceptibility citra digtal proses watermarking, penyisipan watermark pada cover image dianggap sebagai noise dapat menurunkan kualitas citra digital watermarked. Nilai PSNR didapat dengan membandingkan kualitas citra asli atau cover image dengan citra watermarked, semakin tinggi nilai yang didapat menandakan deteksi noise semakin kecil dan kualitas watermarked image dianggap baik. 


\section{Pengujian Pengaruh Alpha Terhadap Tingkat Imperceptibility}

Parameter pengaruh factor embedded (alpha) terhadap tingkat imperceptibility dapat dilihat dari perubahan nilai PSNR, dan $C C$ dari citra hasil embedded atau citra watermarked menggunakan algoritma $D W T$ dengan $S V D$. Pengujian pengaruh alpha dilakukan, karena alpha merupakan level atau derajat ketampakan (visible) watermark terhadap tingkat imperceptibility citra watermarked.

Pada pengujian ini menggunakan nilai alpha yang bervariasi $(0.01,0.02,0.03$, 0.04, 0.05, 0.06, 0.07, 0.08, 0.09, - 0.1) dengan sampel citra motif batik khusus kota surakarta diantaranya motif Kawung, Parang, Satriomanah, Sidomukti, Truntum, Semen Munthilan, dan Sawat, skema pengujian sesuai dengan tabel 1 dengan semua motif citra batik format JPG yaitu kawung di dapatkan data nilai PSNR, CC dengan menggunakan penyisipan Hybrid SVD-DWT, berikut tabel PSNR dan $C C$ dari semua motif batik dengan alpha 0.01 .

Tabel 1

Penyisipan Dengan Menggunakan Hybrid DWT-SVD

\begin{tabular}{lllllll}
\hline $\begin{array}{l}\text { Nilai } \\
\text { Alpha }\end{array}$ & Citra Motif Batik & \multicolumn{3}{l}{ Citra Standar } \\
\hline & $\begin{array}{l}\text { Nama } \\
\text { Batik }\end{array}$ & PSNR & CC & $\begin{array}{l}\text { Citra } \\
\text { Watermark }\end{array}$ & PSNR & CC \\
\hline 0.01 & Kawung & 33.9472 & 0.936603 & Baboon & 32.6933 & 0.92367 \\
\hline 0.01 & Parang & 34.939 & 0.947992 & Elena & 35.6083 & 0.94618 \\
\hline 0.01 & Satriomanah & 29.2389 & 0.82317 & Girl (Tifany) & 35.3063 & 0.930455 \\
\hline 0.01 & Sawat & 32.3394 & 0.942245 & Miscellaneous & 33.7732 & 0.953208 \\
\hline 0.01 & Semen R.P & 31.6653 & 0.834138 & Aerial & 33.8856 & 0.880323 \\
\hline 0.01 & Sidomukti & 31.0941 & 0.653201 & Sequences & 36.644 & 0.942484 \\
\hline 0.01 & Truntum & 29.6941 & 0.852696 & Miscellaneous & 35.4871 & 0.868782 \\
\hline & & & & & & \\
\hline
\end{tabular}

Metode penyisipan hybrid SVD-DWT menunjukkan motif batik yang paling tinggi PSNR nya adalah parang 34.939 sementara dari citra standar yang paling tinggi adalah sequences 36.644, sedangkan nilai cooficient correlation setelah di ekstraksi yang paling tinggi dari motif batik adalah parang dengan nilai 0.947992 artinya tingkat Robutsness nya lebih kuat dari motif yang lain.

Tabel 2

Penyerangan Terhadap Citra Watermark Penyisipan SVD-DWT

\begin{tabular}{|c|c|c|c|c|c|}
\hline Nilai Alpha & \multirow{2}{*}{\multicolumn{2}{|c|}{$\begin{array}{c}\text { Serangan } \\
\text { Parang }\end{array}$}} & \multicolumn{2}{|c|}{$\mathrm{CC}$} & PSNR \\
\hline & & & Sebelum & Setelah & \\
\hline 0.01 & Gausian & 1 & 0.947992 & 0.947213 & 34.939 \\
\hline 0.02 & Salt and Papper & 1 & & 0.903871 & \\
\hline 0.03 & Speckle & 1 & & 0.84205 & \\
\hline Nilai Alpha & Miscelleneous & & Sebelum & Setelah & \\
\hline 0.01 & Gausian & 1 & 0.942484 & 0.934917 & 36.644 \\
\hline & Speckle & 0.01 & & 0.912783 & \\
\hline 0.03 & Salt and Papper & 0.01 & & 0.867644 & \\
\hline
\end{tabular}


Penyisipan SVD-DWT setelah diberikan serangan Noise dengan nilai alpha 0.01, penyisipan akan diambil dengan mengambil nilai $P S N R$ tertinggi dari penyisipan sebelumnya kemudian akan diberikan serangan terhadap masing-masing citra, tabel penyerangan dapat dilihat dari tabel di atas.

\section{Hasil Pengujian Citra Nilai Alpha Yang Beragam}

Nilai $P S R N$ dan $C C$ dengan nilai alpha yang paling rendah hingga paling tinggi menggunakan motif parang, untuk membandingkan citra terbaik dari masing-masing metode dan nilai alpha yang berbeda-beda.

Tabel 3

Hasil Experiment Dari Batik Parang Nilai PSNR Dan CC

\begin{tabular}{|c|c|c|c|c|c|c|c|}
\hline Nilai & \multicolumn{3}{|c|}{ Penyisipan /PSNR } & \multirow[t]{2}{*}{ Nilai } & \multicolumn{3}{|c|}{ Ekstraksi Nilai $C C$} \\
\hline & $S V D-$ & $D W T$ & $S V D$ & & $S V D-$ & $D W T$ & $S V D$ \\
\hline & $D W T$ & & & & $D W T$ & & \\
\hline 0.01 & 34.939 & 34.8878 & 34.9293 & 0.01 & 0.808839 & 0.0140807 & 0.831241 \\
\hline 0.02 & 33.7221 & 33.7499 & 33.671 & 0.02 & 0.95952 & 0.0438747 & 0.963532 \\
\hline 0.03 & 32.2784 & 32.1947 & 32.2186 & 0.03 & 0.986907 & 0.0776841 & 0.988031 \\
\hline 0.04 & 30.8623 & 30.9436 & 30.7868 & 0.04 & 0.988395 & 0.0865276 & 0.990103 \\
\hline 0.05 & 29.5529 & 29.5377 & 29.4658 & 0.05 & 0.989308 & 0.0940927 & 0.991179 \\
\hline 0.06 & 28.3681 & 28.3758 & 28.2818 & 0.06 & 0.989311 & 0.0886047 & 0.991447 \\
\hline 0.07 & 27.3212 & 27.2312 & 27.2429 & 0.07 & 0.989111 & 0.0918112 & 0.991399 \\
\hline 0.08 & 26.3846 & 26.3146 & 26.3156 & 0.08 & 0.989201 & 0.0898735 & 0.991642 \\
\hline 0.09 & 25.5486 & 25.3851 & 25.4851 & 0.09 & 0.958435 & 0.154705 & 0.986048 \\
\hline 0.1 & 24.8049 & 24.6545 & 24.7519 & 0.1 & 0.988121 & 0.0906756 & 0.991036 \\
\hline
\end{tabular}

Terlihat hasil pengujian dari algoritma SVD-DWT menunjukkan hasil PSNR tertinggi namun hasil ektraksi nilai coeficient correlation ditunjukkan oleh algoritma SVD yang lebih mendekati nilai 1. Dengan nilai alpha yang paling tinggi hingga paling rendah.

\section{Kesimpulan}

Dari penelitian dengan judul "Pengamanan Hak Cipta Citra Digital Dengan Teknik Watermarking Menggunakan Metode Hybrid SVD Dengan DWT" disimpulkan sebagai berikut: 1) Pada penerapan Hybrid Image Watermarking DWT dengan SVD nilai alpha dapat mempengaruhi tingkat imperceptibility terhadap citra watermarked, karena nilai alpha menunjukkan tingkat ketampakan (visible) watermark pada cover image. Semakin rendah nilai alpha maka tingkat ketampakan watermark semakin berkurang dan tingkat imperceptibility semakin tinggi. Dari pengujian yang dilakukan dengan object motif batik ditemukan nilai alpha terbaik yaitu nilai alpha 0.01, karena mendapatkan nilai $P S N R$, tertinggi dari yang lainnya. 2) Berdasarkan pengujian tingkat robustness metode Hybrid Image Watermarking DWT-SVD pada subband LL memiliki tingkat ketahanan yang cukup tinggi terhadap upaya menghilangkan watermark yang menjadi identitas kepemilikan sah terhadap suatu citra digital selama citra watermarked tidak direkayasa dengan serangan noise. 3) Motif parang berdasarkan kecerahan gambar 
dengan nilai alpha 0.01 keluaran JPG dengan nilai PSNR 34.9931 tingkat kemiripan dari host image cukup baik dan setelah di ekstraksi tanpa di lakukan serangan menghasilkan nilai corr 0.916089, artinya motif ini yang paling baik dari motif lain setelah di lakukan attact. 4) Motif parang setelah diberikan serangan Gaussian noise nilai corr tidak berubah yaitu 0.916089 dengan di berikan nilai alpha 0.01, ini menunjukkan motif ini dikategorikan tahan dari serangan, tetapi ketika di berikan serangan Salt and peppers noise nilai corr setelah di ektraksi menjadi 0.204693, 0.110056 setelah di berikan serangan specle noise, artinya bahwa beberapa image kuat dari beberapa attact namun lemah dengan attact yang lain. 5) Motif parang ketika di berikan nilai alpha 0.09 mendekati satu nilai PSNR nya 26.2458 sangat rendah dan dipastikan tidak tahan dari attact, jauh dari nilai alpha 0.01, namun ketika di ekstrak nilai corr menjadi 0.974379 pada alpha 0.09 . 


\section{BIBLIOGRAFI}

Allen, J. W. (2002). Chatting Online. The Internet for Surgeons, II (4), 52-57. Google Scholar

Azhar, R., Tuwohingide, D., Kamudi, D., Sarimuddin, \& Suciati, N. (2015). Batik Image Classification Using SIFT Feature Extraction, Bag of Features and Support Vector Machine. Procedia Computer Science, 72, 24-30. Google Scholar

Chang, Y.-J., Wang, R.-Z., \& Lin, J.-C. (2009). A sharing-based fragile watermarking method for authentication and self-recovery of image tampering. Eurasip Journal on Advances in Signal Processing, 2008, 1-17. Google Scholar

Gangadhar, Y., Giridhar Akula, V. S., \& Reddy, P. C. (2018). An evolutionary programming approach for securing medical images using watermarking scheme in invariant discrete wavelet transformation. Biomedical Signal Processing and Control, 43, 31-40. Google Scholar

Gani, A. G. (2014). Pengenalan Teknologi Internet Serta Dampaknya. Jurnal Sistem Informasi Universitas Suryadarma, 2 (2). Google Scholar

Hidayat, E. Y. H. Y., \& Udayanti, E. D. (2011). Hybrid Watermarking Citra Digital Menggunakan Teknik Dwt-Dct Dan Svd. Semantik, 1 (1). Google Scholar

Huang, H. C., Wang, S., \& Pan, J. S. (2004). Genetic watermarking based on transform domain technique. Pattern Recognition, 37, 555-565. Google Scholar

Isac, B., \& Santhi, V. (2011). A Study on Digital Image and Video Watermarking Schemes using Neural Networks. International Journal of Computer Applications, 12(9), 1-6. Google Scholar

Munir, R. (2010). Image Watermarking untuk Citra Berwarna dengan Metode Berbasis Korelasi dalam Ranah DCT. Jurnal Petir, 3 (1). Google Scholar

Naoe, K., \& Takefuji, Y. (2008). Damageless information hiding using neural network on YCbCr domain. International Journal of Computer Sciences and Network Security, 8 (9), 81-86. Google Scholar

Nurhaida, I., Noviyanto, A., Manurung, R., \& Arymurthy, A. M. (2015). Automatic Indonesian's Batik Pattern Recognition Using SIFT Approach. Procedia Computer Science, 59 (December), 567-576. Google Scholar

Rafigh, M., \& Moghaddam, E. M. (2010). A robust evolutionary based digital image watermarking technique in DCT domain. Proceedings - 20107 th International Conference on Computer Graphics, Imaging and Visualization, CGIV 2010, August 2010, 105-109.. Google Scholar

Trixie, A. A. (2020). Filosofi Motif Batik Sebagai Identitas Bangsa Indonesia. Folio, 
Vol 1 No 1, 1-9. https://journal.uc.ac.id/index.php/FOLIO/article/view/1380. Google Scholar

Ukkas, M. I., Andrea, R., \& Anggen, A. B. P. (2017). Teknik Pengamanan Data Dengan Steganografi Metode End of File (Eof) Dan Kriptografi Vernam Cipher. Sebatik, 17 (1), 20-26. Google Scholar

Zhi-Ming, Z., Rong-Yan, L., \& Lei, W. (2003). Adaptive watermark scheme with RBF neural networks. International Conference on Neural Networks and Signal Processing, 2003. Proceedings of the 2003, 2, 1517-1520. Google Scholar

\section{Copyright holder:}

Ondi Asroni, Dedy Ricardo Serumena (2021)

First publication right:

Jurnal Syntax Admiration

This article is licensed under:

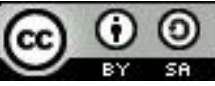

